\title{
History Writing, Adab, and Intertextuality in Late Medieval Egypt and Syria: Old and New Readings
}

\author{
Jo Van Steenbergen
}

Fifty years ago, in 1969, the Islamicist, historian, and pioneer of so-called Mamluk studies Ulrich Haarmann (1942-99) submitted his PhD dissertation on history writing in Egypt and Syria in the period 126o-1340 CE. ${ }^{1}$ Haarmann transformed the text of his dissertation almost immediately into a monograph, which was published in 1970 and entitled Source studies for the early Mamluk period (Quellenstudien zur frühen Mamlukenzeit). ${ }^{2}$ Its main findings were soon also communicated in the summarized format of an article that was published in $1971 .^{3}$ In the same period, almost simultaneously with the young Haarmann's Quellenstudien, another dissertation on exactly the same topic was published in monograph format. This was the work of the American historian and "Mamlukist" Donald Little (1932-2017), entitled Introduction to Mamlūk historiography: Analysis of Arabic annalistic and biographical sources for the reign of al-Malikal-Nāṣir Muhammad ibn Qalā'ūn. ${ }^{4}$ Both Haarmann's and Little's dissertations were published in two newly established German series, Islamkundliche Untersuchungen and Freiburger Islamstudien respectively, each closely related to the invigorating scholarship and academic leadership of Haarmann's PhD supervisor in Freiburg, Hans Robert Roemer (1915-97). Ever since the early 1970s, these publications of Haarmann and Little have had a substantial impact on the relatively small field of the study of late medieval Arabic historiography. With that field's relative growth from the late 199 os onwards, they have continued to retain referential status, even when some of the methods and assumptions that had informed Haarmann's and Little's PhD research in the 196os came under increasing scrutiny. In fact, as will be further detailed in this introduction, the work they began and the insights they brought to the field have continued to inspire, and even define, the study of Arabic history writing in Egypt and Syria between the 13th and 16th centuries.

1 See Glassen, Gedenken.

2 Haarmann, Quellenstudien.

3 Haarmann, Auflösung.

4 Little, Introduction; see Massoud, Donald.

(C) JO VAN STEENBERGEN, 2021 | DOI:10.1163/9789004458901_002

This is an open access chapter distributed under the terms of the CC BY-NC-ND4. Plicenseênbergen - 9789004458901 
Haarmann's thesis on 14th-century Arabic history writing's increased tendency to integrate elements from the distinct literary genres of adab and sir $a$ that is, belles lettres and popular epics - and Little's method of collating 14th-

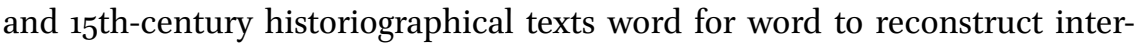
textualities and historiographical practice have certainly also inspired the 13 contributions that make up this volume. These all began as papers that were presented at the fifth meeting of the School of Mamluk Studies (Ghent, July 57 , 2018). They originated in particular as contributions either to this meeting's first day, which was dedicated to the theme of historiography, or to two related historiography sessions that were organized during the next two days. How these chapters tie in with their wider contexts of late medieval Arabic history writing and its study in recent decades, and how many of them actually represent within those contexts not just related but also new readings, will be sketched in this introduction.

Haarmann's intention in his Quellenstudien was not just to highlight and illustrate a trend of "Literarisierung" of history writing. He also insisted on the need to ask questions of social import and impact to explain, or at least better understand, the manifestation of this phenomenon of change and fluidity in a literary and intellectual genre whose parameters and boundaries were long thought to have been canonized in the 9th and 1oth centuries. Haarmann, therefore, brought to attention the need to consider wider contextual issues of audience and authorship, as well as the effects of their substantial transformations in exactly the same period. In this context, he referred to the following statement by the French Orientalist Edgard Blochet (1870-1937), from the introduction to Blochet's edition and translation of the chronicle by the Egyptian Christian historian al-Mufaḍdal b. Abī l-Faḍāili (d. 1358): "At the time of the Mamluk sultans, everyone in Egypt was more or less marked by the urge to write texts of history, grand texts of history in particular, as voluminous as possible. [This was true] especially for people who had no business with [text writing], and whose functions in live were of a totally different order." ${ }^{5}$ For Blochet, this popularity and interest from the expanding ranks of what he called "amateurs" helped to explain late medieval changes in Arabic text writing as typical exponents of "post-Classical" decay and decline. Haarmann, and to a much lesser extent also Little, at least attempted to start thinking beyond the latter Orientalist stereotypes and to understand these substantial transformations more in

5 "A l'époque des sultans mamlouks, en Egypte, tout le monde fut plus ou moins atteint de la manie d'écrire des histoires, de grosses histoires principalement, les plus volumineuses que l'on pouvait, surtout les gens don't ce n'était point l' affaire, et dont les fonctions dans la vie étaient tout autres." Blochet, Moufazzal 365 (23); Haarmann, Quellenstudien $130 n 2$. 
their own right. For them, they were manifestations of a late medieval SyroEgyptian particularity, related to-as Little nevertheless only summarily dared to suggest- "variations [of] the historian's originality." ${ }^{6}$ The three modes in which these transformations presented themselves, and have so far been studied, will be surveyed below. This will then be followed by an appreciation of how more recent research has been moving beyond questions of originality to understand these manifold transformations in the quantity, context, and genre of history writing between the 13 th and early 16 th centuries.

First among these transformations was the simple and well-established fact that, as Blochet also implied, between the 13th and early 16th centuries more Arabic historiographical texts were written in Egypt and Syria (as well as in the strongly interconnected Arabian region of the Hijaz) than ever before or after in premodern Islamic history. Konrad Hirschler, in his survey chapter on the study of late medieval Syro-Egyptian historiography in the early 21st century, speaks of an "explosion of historical writing" that for him already had begun with "some first inklings of change towards the end of the twelfth century in the early Ayyubid period." 7

Haarmann and Little saw the late 13th and early 14th century as a first major moment in this acceleration of history writing, coinciding with the three successive reigns of Sultan al-Malik al-Nāșir Muhammad b. Qalāwūn (r. 1293-4; 1299-1309; 1310-41). Both, therefore, chose to focus their research on this long moment of dynastic sovereignty and cultural efflorescence. Haarmann estimated that for this half century of Syro-Egyptian history, more than a dozen contemporary chronicles have been preserved and that at least a similar number of contemporary texts of history have only left—in the late 196os-minor traces at best. ${ }^{8}$ Little confirmed that the narrative sources for this period "are among the richest to be found for any phase of Islamic history." ${ }^{\prime 2} \mathrm{He}$, therefore, made a selection of chronicle and biographical texts that were available to him, written by seventeen contemporary and eight later historians, and compared how all of them reported the same events or the same biography from the late 1290 s and mid-13oos in related or differentiated ways.

6 Little, Introduction 2.

7 Hirschler, Studying 162.

8 Haarmann, Quellenstudien 130.

9 Little, Introduction 94. 
In the early 20oos, one of Little's graduate students, Sami Massoud, engaged in similar dissertation research on the entanglement of the historiographical production that was concerned with the late 1370 os to the early 1400 s and the reigns of the sultans al-Malik al-Ẓāhir Barqūq (r. 1382-9; 1390-9) and his son al-Malik al-Nāșir Faraj (r. 1399-1405; 1405-12). His analysis identified a dozen chronicles by nine Syrian and Egyptian authors as contemporary with this eventful turn of the 14th to 15th centuries, and it considered six texts by later authors as equally relevant for comparison and collation. ${ }^{10}$

More recent research has furthermore established that the biggest moment - in quantitative if not in qualitative terms - in the history of late medieval Arabic history writing was the subsequent period, between the 1410 and the 1460 s, when especially a series of formerly mamlūk sultans and their distinct courts succeeded each other, from the violent constitution of the reign of Sultan al-Malik al-Mu'ayyad Shaykh (r. 1412-21) to the equally violent dissolution of the entourage of Sultan al-Malik al-Zāhir Khushqadam (r. 1461-7). Described by Little in a later survey publication as a period in which history writing was "culminating in the Mamlūk 'imperial bureaucratic chronicle,"'11 this particular half century witnessed a historiographical quantum leap that was realized by some 30 Egyptian, Syrian, and Hijazi authors. Together, they penned an impressive corpus of more than 80 texts, ranging from voluminous chronicles and biographical dictionaries to single-volume historical monographs and treatises and often integrating texts from 14th, 13th, and earlier centuries with contemporary materials and observations. ${ }^{12}$

In the final half century of the late medieval period, dominated by the reigns, entourages, and extensive social and cultural patronage of the sultans alMalik al-Ashraf Qāyitbāy (r. 1468-96) and Qānișawh al-Ghawrī (r. 1501-16), this remarkable early to mid-15th-century acceleration in historiographical production seems to have slowed down again. For this period, the writerly activities of a dozen Egyptian, Syrian, and Hijazi authors are currently known to have jointly produced some 20 works of history. ${ }^{13}$

In general, for the entire late medieval period between the end of the 12th and the beginning of the 16th century, some 150 Arabic texts of history are thus currently known to have been written in the closely interconnected regions of Egypt, Syria, and the Hijaz. They represent an important share in the output of up to about 70 authors. These approximate numbers were moreover

\footnotetext{
10 Massoud, Chronicles; Notes.

11 Little, Historiography 413; quoting from Khalidi, Arabic 183.

12 See Van Steenbergen et al, Fifteenth-Century.

13 Petry, Protectors 5-9; Meloy, Imperial 29-3o.
} 
not equally spread over these three long centuries, but they rather witnessed a substantial accumulation in the 15th century. No less than half of these many tens of authors were active in the period's closing century, and they produced two-thirds of all the era's historiographical texts. Especially the middle of this century stood out as decades of extremely intense and widely appreciated historiographical practice, when the likes of al-Maqrīzī (ca. 1363-1442), Ibn Ḥajar (1372-1449), al-'Aynī (1361-1451), Ibn Taghrībirdī (1411-70), and alSakhāwī (ca. 1427-97) left their marks on the booming business of Arabic history writing for centuries to come.

As Blochet already surmised, the unprecedented quantitative leap in Arabic historiographical production coincided with equally substantial changes in the historian's profile. Basically, not only did the historians' ranks expand, they also diversified. Whereas scholars-traditionists, such as the likes of early Arabic historiography's champion al-Tabarī (d. 923), continued to appear as predominant, they were joined in the practice and appreciation of history writing by courtiers-bureaucrats of varying backgrounds and specializations. Furthermore, "the two groups were certainly not mutually exclusive," Little rightly observed, explaining how most of the latter "would have had some exposure in the course of their education to the art and science of hadith and its transmitters, which continued to influence scholarly historiography from its inception to the time in question." For the scholars-traditionists, Little also remarked that "many of the 'ulama $\bar{a}$ ' served in some official capacity or another associated with judicial institutions." ${ }^{14}$ In a programmatic publication on so-called ${ }^{15}$ Mamluk literature, Thomas Bauer identified this blurring of boundaries as a more general aspect of the late medieval era's cultural and intellectual history. He graphically described it as 'the process of 'ulamaization of adab' [that] was counterbalanced by a process of 'adabization of the ulama,' who in the meantime made the adab discourse of the kuttāb their own." 16 Eventually, informed by the work of Konrad Hirschler on reading practices in this period, Bauer concluded that "even this description does not do justice to the increasing par-

\footnotetext{
14 Little, Historiography 413.

15 For a critique of the habit of identifying social and cultural phenomena such as late medieval Arabic literature with the qualifier "Mamluk," see Van Steenbergen, "Mamlukisation" 2-6.

16 Bauer, Misunderstandings 108; repeated in, Ayna 6.
} 
ticipation of traders and craftsmen in literary life to such a degree that there was even a gradual blurring of the boundaries between 'high' and 'popular' literature."17

Even though no traders or craftsmen are (currently) known to have produced any work of history proper, ${ }^{18}$ the latter qualification certainly captures well the fluid as well as intense-even very popular-context of literary authorships within which the writing of history also thrived. ${ }^{19}$ Haarmann, in his Quellenstudien, had already pointed to this process as one of deep social transformation and even described it as no less than a "radical popularization of the field" of history writing. ${ }^{20}$ Building on an impressionistic typology of profiles of early 13th-century historians, first devised in the 1950s by Hans Gottschalk, Haarmann had actually already tried to get a closer grip on those fluid and expanding ranks of historians, suggesting that they could usefully be divided up in four overlapping categories. A first group in this more detailed GottschalkHaarmann typology were historians who pertained to the diverse ranks of late medieval Syro-Egyptian powerholders, such as the historian, geographer, and Ayyubid sultan of Hama Abu l-Fidā' (1273-1331) or the leading mamlük amir in Egypt, Baybars al-Manșūrī (ca. 1245-1325). Second came the ranks of courtiers, which in many ways overlapped with the preceding category, but importantly, also included leading experts of court communication such as the royal secretaries Ibn 'Abd al-Zāhir (1223-92) and his nephew Shāfi' b. 'Alī (1252-1330). A third important group of historians were all scholars, mostly specialists of hadìth, that is, traditionists, and ranging from the likes of 'Izz al-Dīn Ibn al-Athīr (116o-1233) in Mosul to those of al-Dhahabī (1274-1348) in Damascus. A fourth category of historians was then added to Gottschalk's typology by Haarmann to account for his identification of a "radical popularization." These concerned the less high profile military, courtly, and scholarly peers, followers, and supporters of the first three categories, from the rather obscure likes of the military men Ibn al-Dawādārī (fl. early 14th century) and al-Yūsufì (d. 1358) to the scholars of hadīth and notary witnesses al-Jazarī (126o-1338) in Damascus and Ibn al-Furāt (ca. 1334-1405) in Cairo.

This particular typology was first and foremost devised as a tool to better describe and represent the fluid diversity of historiographical authorship in 13th- and early 14th-century Syria and Egypt. It is therefore not only rather

17 Bauer, Mamluk literature 23.

18 But see the Yemeni historian al-Khazrajī (d. 1409), described as originally a craftsman (Sadek, Notes); I am grateful to Daniel Mahoney for this suggestion.

19 See also Hirschler, Islam 279-81.

$20 \quad$ Haarmann, Quellenstudien 131. 
specific for the first of this late medieval period's three centuries, it was also externally imposed by modern scholarship and merely offered a useful starting point for Haarmann in the late 196os to describe the authorial diversity that was responsible for the era's explosion of historiographical texts, at least during its opening century. As Li Guo summarized in another survey article on the study of history writing in late medieval Syria and Egypt, published in 1998, another typology that has been somewhat more in vogue for some time among modern scholars distinguishes between historians related to the sultan's court in Cairo and those that were active members of the traditionalist community of scholars of hadith and related knowledge practices in Damascus. ${ }^{21}$ This imagination of a sociocultural dichotomy is again specific for the late 13th and early 14th centuries, best known through the studies of Haarmann and Little, and of others, including Li Guo, in their wake. As a result, not only its actual reality - following Little, often considered referring to distinct Syrian and Egyptian schools of historiographical practice ${ }^{22}$ - but also its wider representativity remain even more debated than has ever been the case for the Gottschalk-Haarmann typology. Just as the latter, also this DamascusCairo typology — and Little's abovementioned more general model of scholarstraditionists and courtiers-bureaucrats that has been derived from it-may nevertheless be considered useful. It enables, above all, a general appreciation of both the different but defining sociocultural contexts of history writing (panegyrist courtship and traditionist/traditionalist scholarship) that existed in the 13th and early 14th centuries, and the many changes of the 14th and 15th centuries. These included the blurring of boundaries between Syrian and Egyptian historiography and between traditionalists and courtiers. They also involved the increasing numerical preponderance of religious scholars with elitist and courtly, as well as more popular and local, profiles and especially of strongly interconnected networks of hadith specialists. This can arguably be understood as another, specific, process of the 'ulama'-ization of the literary genre of Arabic history writing, in the course of which the historiographical achievements of powerholders, courtiers, and any others who were not also 'ulam $\bar{a}^{\text {' }}$ were dwarfed by those of traditionalists and traditionists.

The impact of traditionalist scholarship on the formation of late medieval Arabic historiographical practices was enormous. Damascus at the turn of the 13th and 14th centuries in particular appears as a thriving environment for both this scholarship and these practices. As Li Guo summarizes,

21 Guo, Mamluk 31-2. For traditionalism, see now Holtzman, Anthropomorphism.

22 Little, Introduction 98. 
this environment - organized around the writings of al-Jazarī (126o-1338), alYunīnī (d. 1326), and al-Birzālī (1267-1339)—is therefore considered to have recalibrated the parameters of Arabic history writing as a genre in ways that remained determinant into the 16 th century:

Al-Jazarī, al-Yunīnī, and al-Birzālī's contribution to medieval Islamic historiography was that they perfected and reformulated the mode started by Sibț ibn al-Jawzī, a mode wherein the two basic sections of each year's record, namely the hawādith (events) and wafayāt (obituaries), were evenly presented, and in which the latter was also effectively enhanced by adding to it the hadiths transmitted on the authority of, and $a d a b$ output by, the a'yān of the era, namely the 'ulam $\bar{a}$, and, less frequently, some ... statesmen. History as recorded by these Syrian historians is not only a record of events, but a register of Muslim religious learning, as well as a selective anthology of the cultural and literary heritage of the time. $^{23}$

This integration of events, obituaries, and concerns for learning and heritage in historiography was actually also noted and studied, mainly as an expansion of historiography's literary interests, however, by Ulrich Haarmann. In his Quellenstudien he explained this "literarization" as a consequence of historiography's growing popularity, which involved diversifying audiences, tastes, and readership expectations. Haarmann actually saw a direct causal relationship between this growing popularity on the one hand and the 13th-century formation of the sultanate in Egypt and Syria and the stabilization of urban social formations and infrastructures in its wake on the other. More specifically, he explained the change and expansion of historiography's interests with readers and writers alike that ensued from this in the early 14th century: "An audience of longstanding and entrenched interest in and orientation towards literary Adab turned to the literarised Chronicle, which was manifestly also informed, or at least intrigued, by the folk romances that were popular in these circles. The growing demand for Adab-History encourages in its turn ever more writers of mostly lower status and for mostly material reasons to try their luck in historiography, without however having subjected themselves to the strict training of traditionist scholarship." ${ }^{4}$ This particular interpretation of the interacting

23 Guo, Mamluk 38.

24 Haarmann, Quellenstudien 134; "ein bislang weitgehend am literarischen Adab interessiertes und orientiertes Publikum wendet sich der literarisierenden Chronik zu, offensichtlich auch disponiert oder doch wenigstens angeregt durch die in diesen Kreisen 
popularization of late medieval writing and reading practices in Egypt and Syria was eventually studied more thoroughly by Thomas Bauer and Konrad Hirschler. Bauer pursued this above all in a chapter that refined his interpretation of the aforementioned adabization- $u l a m a \bar{a}$-ization process, also engaging with what he identified as Hirschler's thorough analysis of "the background of this process." Bauer actually usefully summarizes that "Hirschler describes two interrelated developments - textualization (increased use of the written word) and popularization (increased participation of non-scholarly groups in cultural activities)—during the [late medieval] period that led to the rise of a "literate mentality." ${ }^{25}$ Late medieval Arabic historiography's involvement in this much wider process of the "popularization" of reading practices still requires much more research. In the meantime, Konrad Hirschler has already been leading the way with the publication, in 2016 and 2020, of two detailed monograph studies of particular instances of textual reception. These concerned, respectively, a local endowed library in Damascus and its catalog, written in the $1270 \mathrm{os}$ and listing more than 2,00o titles, and a private library collection from a Damascene hadith scholar and the book register that was drawn up for its endowment in 1492, listing some 6oo manuscripts. They illustrate how, in the 13th century, traditionalist scholarship in this particular corner of Damascus was adabizing in pluralistic and diverse ways - or was perhaps intrinsically as adabized as Haarmann in the above quote from his Quellenstudien had already assumed for readerships in general - and how in 15th-century Damascus that complex intellectual fold of traditionalist scholarship was radically reconfigured. What is relevant in the present context, however, is the fact that these two studies also illustrate how, in the $13^{\text {th }}$ as well as the $15^{\text {th }}$ century, history writing only represented a small fraction of the textual materials that made up these collections, which were oriented heavily toward the genres of prose and poetry in the former and hadīth studies in the latter case. Both, therefore, also suggest that textual practices other than historiography interested readers much more, even when history writing seems to have integrated many aspects of those other textual practices, from hadīth studies to adab. ${ }^{26}$

populären Volksromane. Die steigende Nachfrage nach Adab-Historie wiederum ermutigt immer mehr, vor allem auch niederigeren Ständen angehörigen Literaten, aus wohl vorwiegend materiellen Gründen ihr Glück in der Historiographie zu versuchen, ohne daß sie sich dem Rigorosum einer traditionswissenschaftlichen Ausbildung zu unterziehen hatten."

25 Bauer, 'Ayna 6; referring to Hirschler, Written esp. 197.

26 Hirschler, Medieval Damascus; Monument. 
A third major change that Haarmann identified for late medieval Syro-Egyptian historiography, next to an explosion of texts and the changing profiles of their authors and audiences, concerned this integration of other textual practices into the set frames of, especially, Arabic chronicle writing. This, as it were textual blurring of boundaries, was at one point identified by Haarmann in his Quellenstudien as the "literarization of historiography" and the "historization of $a d a b$ " and at another point as "the legendarization of historical texts." Basically, Haarmann argued that the serious business of history writing proper (tārīkh) became directly related to the amusing textual performance of popular epics (sir $a$ ) via the mediation of $a d a b$, understood by him in this context as "a mixed genre, that combines poetry and rhymed prose, anecdotes and epigrams, edification, and entertainment." ${ }^{27}$

Haarmann argued in particular that a divergence occurred between the external features and the internal characteristics of many late medieval Arabic history texts. While the former continued to abide by the annalistic and biographical formal schemes that had been set for the genre of Arabic history writing ( $t \bar{a} r \bar{i} k h)$ between the 1oth and 12th centuries, he saw the latter opening up to the integration of textual practices from both adab and sira. The inclusion of a substantial number of poems and related textual specimens of $a \mathrm{dab}$ "literarized," or "adabized," history writing. The enrichment of reports of historical events and people's scholarly or political careers with anecdotes and wondrous and remarkable stories ('ajāì wa-gharāìib) and with dreams and related occult phenomena enhanced the entertainment value of the genre. It was further popularized by the appearance of vernacular forms from the spoken registers of Arabic in the written text, as well as by creative rewritings of history. Haarmann even went as far as to define these internal changes as involving a process of "de-historization" (Enthistorisierung), explaining this as "giving up historical method and accuracy for the benefit of aesthetic-literary values in situations in which both are incompatible." ${ }^{28}$ Finally, these modifications in the textual

27 Haarmann, Quellenstudien 137 ("Literarisierung der Geschichtsschreibung ... Historisierung des Adab"), 165 (“die Legendarisierung der Historischen Texte"), 16o ("ein Mischengenre, das Poesie und Kunstprosa, Anekdoten und Sinnsprüche, Erbauung und Unterhaltung in sich vereinigt"). Haarmann actually synthesized, applied, and furthered insights on the "literarization" of late medieval Syro-Egyptian history writing that had already been formulated by predecessors in German "Orientalist" scholarship, such as Pauliny (Anekdote), Schregle (Sultanin), von Grunebaum (Medieval 250-7), and Richter (Geschichtsbild).

28 Haarmann, Quellenstudien 180. 
practices of history writing itself were considered by Haarmann to be a historical and, as seen above, socially determined process. He saw these trends of "literarization" and "adabization," of "legendarization" and "de-historization," and of popularization developing over time and across the expanding historiographical field, appearing first in history texts from the later 13 th and early 14 th centuries - by al-Jazarī in Damascus and especially Ibn al-Dawādārī in Cairoand culminating in the early 16 th century in the chronicle of Ibn Iyās (d. 1524). ${ }^{29}$

Haarmann's particular vision of a growing divergence in historiographical practice between the external stability and inner transformations of Arabic chronicles came to be referred to (somewhat reductively perhaps) as his "Literarization" (Literarisierung) thesis. Formulated along a highly complex and nuanced argumentation in the late 196os and early 1970s, this thesis was engaged with in diverse ways between the 1970s and early 200os. It was (mostly implicitly) embraced and expanded to also include the chronicle's major historiographical partner, the biographical dictionary, in Hartmut Fähndrich's almost simultaneously pursued study of a seminal late medieval specimen of this genre: the Wafayāt al-Ayyann (The obituaries of celebrities) of the Syrian legal scholar Ibn Khallikān (1211-82). Written in Cairo between 1256 and 1274 and consisting of a collection of substantial obituaries-biographies of 855 different individuals who were considered exemplary by the author, "Ibn Khallikān's Wafayāt," Fähndrich argued, "represents a certain literarization of the genre of 'biographical dictionary' in that for the presentation of a great part of the material the literarizing approach of adab is employed." ${ }^{30}$ Haarmann's "literarization" thesis was most directly criticized in the work of Bernd Radtke, published between the early 1980s and 199os. ${ }^{31}$ Radtke basically argued that "literarization" was not a general nor a new late medieval phenomenon and that elements of $a d a b$ and sira, including especially poetry and mirabilia, had been an integral component of historiographical practice since at least the 1oth century. He also was very critical of Haarmann's notion of "de-historization," explaining that historiography's truth claims operated differently from what Haarmann had assumed. In fact, Radtke rather stressed long-term continu-

29 See, e.g., for "legendarization" Haarmann, Quellenstudien 165: "The legendarization of historical texts reached a new culmination point in the fifteenth century-that is, from Ibn al-Furāt, Ibn Duqmāq and al-Maqrīzì onwards—, and especially at the beginning of the sixteenth century in the work of Ibn Iyās."

30 Fähndrich, The Wafayāt 439-40 (for a summary acknowledgment of Haarmann's work, remarkably represented only as "a study of topoi in Mamlūk historiography," see 435n11). See also Fähndrich, Man; Fähndrich, Compromising.

31 See the useful summary of this debate between Radtke and Haarmann in Guo, Mamluk $33-6$. 
ities, especially as dictated by the salvationist and globalizing ambitions of Islamic history's major chronicles, including some from the later medieval period. Whereas history writing in this context serves the purpose of presenting and conforming to a salvationist and revealed truth of universalist dimensions (a purpose that was equaled by Radtke with the notion of tașdiq ), in other textual contexts, it may also serve more specific cultural, practical, and entertaining purposes (tacajjub). In fact, "from the thirteenth century onwards," Radtke explains, "a mixture of salvationist, cultural, and world history as entertainment became the norm." ${ }^{32}$ For Radtke, these were therefore not increasingly lesser forms of history writing but rather represented different discursive registers that historians could employ to pursue their multivalent textual ambitions.

Haarmann, in his review of Radtke's Weltgeschichte und Welbeschreibung im mittelalterlichen Islam, was happy to accept the latter correction but fiercely argued for the validity of his thesis of "literarizing" changes and against Radtke's notion of static continuity. "What is decisive," Haarmann insisted, "is the quantitative change, the sharp increase of literary insertions in the writing of those few historians who, as a corollary, met the criticism of their more traditionally minded peers." 33 This qualification of Haarmann's original "literarization" thesis as a diverse range of textual practices that complemented rather than replaced more traditional historiographical trends and that meant a break with the past, especially in quantitative terms, was further confirmed and refined by others. These include above all Thomas Herzog for the integration of sira materials, Otfried Weintritt for a particular late 14th- and early 15 th-century set of textual examples of the fusion of $a d a b$ and tārīkh, and Li Guo for the history writing of early 14th-century Damascene traditionalists. ${ }^{34}$ As suggested in his quote above on the traditionalists/traditionists al-Jazarī, al-Yūnīnī, and al-Birzālī and their role in the integration into the historiographical practice of descriptions of events, obituaries, and concerns for learning and heritage, Guo definitely saw a distinctive model of history writing emerging amid their collaborative network of colleagues and texts, with a substantial impact on historiographical practice from the later 14th century onwards. "This method of ta'rikh writing," Guo explains, "was started by the Hanbalī Ibn al-Jawzī of Baghdad, transmitted through his grandson Sibț Ibn al-Jawzī of Damascus, and was eventually polished in the hands of the Ḥanbalīs al-Yūninī, of Ba’labakk, and al-Jazarī, of Dam-

32 Radtke, Weltgeschichte 204-5; translated quote from Guo, Mamluk 35.

33 Haarmann, Review 135 (italics in the original).

34 Herzog, Geschichte esp. 391-2; Weintritt, Formen; Guo, Early esp. 81-96 (Chapter Four: "The Dhayl and early Mamluk Syrian historiography: The making of a model"). 
ascus." ${ }^{35}$ This particular method of traditionalist historiography, as Guo reconstructed it, is one of annalistic chronicle writing in which factual descriptions of a year's events and obituaries for a year's important deceased are presented as distinct parts of an annal. At the same time, obituaries-biographies in this model display a clear bias toward hadith transmitters, giving priority to traditionists and their scholarly track record and including also many specimens of their adab-related output, especially poetry. ${ }^{36}$ In al-Yūnīnīs continuation (dhayl) of Sibț Ibn al-Jawzì's (1185-1256) universal chronicle, the famous Mir'ät al-Zamān, Guo counted some 2,20o poems, spread over the text's rather limited whole of 58 annals (for the hijri years from 654/1256 to 711/1312) and serving, in Guo's reading, the double purpose of entertainment and recording what was popular in al-Yūnīni’s and his peers' time. ${ }^{37}$

Interestingly, Guo also noted — contra Haarmann — the extent to which this particular model was different from that of early 14th-century Egyptian history writing, including even Ibn al-Dawādārì's "literarizing" chronicle. "[A]ll of these [Egyptian texts of history] evidently followed," Guo suggests, "what may be called 'the Ibn al-Athīr model,' i.e., basically an annalistic form following that of al-Tabarī, with a few obituaries of rulers or statesmen attached at the end of the text for each year."38 Basically, obituary notes in this model were brief, and certainly not biased toward traditionists, and quoted poetry consisted primarily of panegyrics (madih ) for sultans rather than any representative adab anthology. Guo, therefore, concludes also that "while the heroes of the Egyptian chronicles and manuals were the $[\ldots]$ sultans and statesmen, the attention of Syrian historians was focused on their fellow a yyann, the notable learned men, especially those prominent hadìth scholars." ${ }^{39}$ As historiographical practice continued, however, and traditionalist scholars increasingly led the way, the rich Syrian textual tradition of al-Jazarī, al-Yūnīnī, and al-Birzālī became an important source of historical information, not only for later Syrian historians but also for the growing numbers of their Egyptian counterparts. In this process of confrontation, integration, expansion, and transformation of practices of history writing, these Syrian and Egyptian models fused and became an intrinsic component of the creative context within which so much history was written in

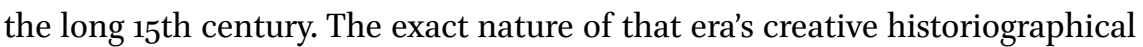
context, however-as with the late 13th and early 14th centuries undoubtedly

35 Guo, Early 86.

36 Guo, Early 82-6.

37 Ibid. $87-93$.

$38 \quad$ Ibid. 93 .

39 Ibid. 94. 
of much greater complexity than Haarmann's "literarization" thesis had first suggested-remains largely unstudied. ${ }^{40}$

As indicated at the beginning of this introductory chapter, unlike this creative context, the process of the Syrian and Egyptian historiographical traditions' confrontation and integration has been given much more attention, especially as a result of Donald Little's pioneering work. Little's method was one of collating 14th- and 15th-century historiographical texts word for word to reconstruct intertextualities and historiographical practice. His driving force was a search for historical originality and textual accuracy and reliability. As a result, Little considered what Haarmann identified as trends of "literarization" in his own negative way as a form of "de-historization." For Little, anecdotes, wondrous stories, and their like were an aberration from the annalistic historiographical norm, which, above all, added to the modern historian's workload in "the admittedly laborious process of collation and analysis to compensate for the sins and errors of his sources."41 The outcome of his own laborious process of collation and analysis reconstructed particular textual interdependencies for Syro-Egyptian history at the turn of the 13th and 14th centuries and established the centrality within those networks of texts and the historical data of particular chronicles. ${ }^{42}$ The latter included the Syrian textual cluster of al-Jazarī, al-Yūnīnī, and al-Birzālī but also the Egyptian chronicles of Baybars al-Manșūrī and al-Yūsufî. Little also fleetingly identified the multivolume encyclopedic work of the Egyptian court administrator al-Nuwayri (1279-ca. 1332) and then later the universal chronicle of the traditionist-scholar Ibn al-Furāt (d. 1405) as important textual conduits that remoulded this earlier material and thus prepared it to be reused in the creative context of the $15^{\text {th }}$ century. ${ }^{43}$

In the early 20oos, Little's aforementioned graduate student Sami Massoud used his teacher's method of a word-for-word collation of sample annals to study the textual practices of another comprehensive corpus of Arabic chronicles. Massoud's purpose was to reconstruct the networks of historical reports that connected, and informed about, historiographical texts, authors and prac-

40 But see the following relevant studies: Bauden, Maqriziana (see also below); Perho, AlMaqrīzī; Ibn Taghrībirdì’s portrayal; Ibn Taghrībirdī's voice; Tadayoshi, Analysis of 'Abd al-Bāsiț; Wasserstein, L'oeuvre d'Ibn Iyās; 'Izz al-Dīn, 'Abd al-Bāsiț; Ibn Hajar; al-Maqrīzī; Arba'at Mu'arrikhin.

41 Little, Introduction 98.

42 But see Cahen's review of Little's Introduction, noting that Little's method of sampling data from three randomly chosen annals and neglecting explicit and implicit intertextual references made elsewhere in his text corpus generates very partial and inconclusive results only; Cahen, Review 224.

Little, Introduction 96. 
tices for the period from the late 1370s to the early 140os. Driven by concerns for originality in both historical and more literary terms, he not only identified "the five most copied and used original sources" for the history of this period but also "the systemic interrelation between al-Maqrīzī's Kitāb al-Sulūk and Ibn alFurāt's Tärīkh al-Duwal" among these big five. ${ }^{44} \mathrm{He}$ simultaneously concluded, as both an implicit reiteration of Haarmann's qualified "literarization" thesis and a call to move beyond Little's quest for originality, that these texts need to be considered as: "more than simple repositories of facts that help modernday historians in their attempt to reconstruct the past: they also need to be approached as literary constructs that reflect the social configuration of the environment in which they were written and 'the cultural norms and conceptual assumptions' that played a role in their production." ${ }^{\text {45 }}$

\section{$4 \quad$ New Readings in Late Medieval Arabic Historiography}

To date, especially the central historiographical practices of al-Maqrīzì and, to a lesser extent, of Ibn al-Furāt have been the object of studies that are pursued along what Massoud also identified as the way forward in presentday historiographical studies. These studies all focus in different ways on the constructed-ness of al-Maqrīzì's and Ibn al-Furāt's texts of history. In the case of the former, since the early 2ooos, the work of Frédéric Bauden in particular has substantially deepened understandings of al-Maqrīzìs working methods as a prolific historian in the early 15 th century. This continues to be achieved by combining Little's method of collation and intertextual reconstruction with a material turn to manuscript studies and, thus, by integrating into the analysis the detailed and painstaking codicological study of extant fair copies, drafts, notebooks, and marginal notes. ${ }^{46}$ In the case of Ibn al-Furāt, the recent monograph by Fozia Bora has taken Little's method, Bauden's material turn, and the question of Ibn al-Furāt's universal history's interconnectedness and constructed-ness to another level by relating understandings of its intertextuality to interpretive turns that have been made in archival studies. Bora actually attempted to return, in a more nuanced sense, to Little's quest for originality. She developed an interesting argument for a consideration of Ibn al-Furāt's

\footnotetext{
44 Massoud, Chronicles 191.

45 Massoud, Chronicles 195-6, quoting also from Shoshan, Poetics ix.

46 See Bauden, Maqriziana i-xi; Al-Maqrïzı’s collection of opuscules. See also Bauden's Bibliotheca Maqriziana; Van Steenbergen, Caliphate and kingship: Part 1: Study—-the cultural biography of a fifteenth-century literary text.
} 
chronicle-presented by Bora as a representative specimen of late medieval Arabic chronicle writing in general-as a form of documentation and as the materialization of a specific archival practice; in Bora's reading, via that practice, an author pursued both "knowledge-making" and its "conservation" in order to "'eternalize' the past," meet the moral-didactic and sociocultural needs of contemporary and future readerships, and circumvent the era's highly volatile conditions of life. ${ }^{47}$

In new readings such as Bauden's and Bora's, then, not just the complex constructed-ness of texts of history is being studied but also the social, intellectual, and practical agencies of historians. This links up with another line of research that remains prominent and promising, that has arguably developed more autonomously from the Haarmann-Little tradition, and that has taken the changing nature of historiographical authorship in late medieval Egypt and Syria as its main object of research. Already in the 1950s and 196os, Franz Rosenthal (1914-2003), in the first and second editions of his pioneering History of Muslim historiography, almost heedlessly captured a trend toward a more explicit and self-conscious understanding of historiographical practices that marked, especially, the field of Arabic history writing in its highly prolific 15th century. Rosenthal famously presented, in the second part of his History, translations of three theoretical discussions on the methodology of history writing that were authored in the early 138 os, the early 1460 s, and the early 1480 s. They included a short text by the traditionalist scholar al-Kāfiyājì (d. 1474), entitled The short work on the science of history writing (al-Mukhtașar fì 'ilm al-tārīkh) and identified by Rosenthal as "being the oldest Muslim monograph on the theory of historiography known to us." ${ }^{8}$ They also included a much longer text by the Egyptian traditionalist scholar, historian, and biographer al-Sakhāwī (142797), The open denunciation of the adverse critics of the historians (al-I'län biTawbīkh li-man dhamma ahl al-ta'rïkh), which, as a theorizing survey of Arabic history writing, greatly informed the organization and argument of Rosenthal's own History. Its apologetic title is actually directly related to the traditionalist

47 Bora, Writing. This archival approach was arguably also implicitly present, or at least announced already, in Elias Muhanna's study of encyclopedism and compilation in alNuwayrīs Nihàyat al-Arab, in which he also pursues better understanding of "the ways that the ... compilers position themselves vis-à-vis the archive they were compiling." Muhanna, World; based on the author's doctoral dissertation (Harvard University, 2012). The "archival turn" was most explicitly called for as a promising approach for the study of late medieval Arabic historiography, and of biographical collections in particular, by Konrad Hirschler (Studying 175-80); it was further inspired by Hirschler's work on archival practice (From archive).

48 Rosenthal, History 245 . 
agenda of this as well as the other two texts. History writing along a specific methodology was presented by these authors as a constituent component of traditionalist Islamic scholarly practice, which conformed to the traditionalist profiles of al-Kāfiyājī and al-Sakhāwī and, as explained before, the majority of historians in the long $15^{\text {th }}$ century. For all of them, this practice was rooted in longstanding precedents that included early and contemporary hadith scholarship but also the aforementioned examples of the traditionalist scholars, historians, and men of influence Ibn al-Jawzī (1126-1200) in Baghdad and alDhahabì (1274-1348) in Damascus. ${ }^{49}$

This more conscious appearance of historiographical authorship has been studied in recent years not so much, however, from the theoretical perspective of traditionalist scholarship and its practice, as had been only superficially touched upon many decades ago by Franz Rosenthal. ${ }^{50}$ Rather, this aspect in the changes affecting authorship has been understood and researched especially from a more textual perspective, from the acknowledgment of authors' growing presence in and meddling with their texts of history. Most conspicuous in this respect is undoubtedly the growing phenomenon of the author's self-referencing. The latter is epitomized by the occasional presence of autobiographical notes and, especially, by a number of autobiographical texts. ${ }^{51}$ One of these texts is the closing part of Ibn Khaldūn's (1332-1406) historiographical trilogy, tellingly entitled Biographical sketch on Ibn Khaldün and the account of his travels in the west and in the east (al-Ta'rîf bi-Ibn Khaldün wa-rihlatihi gharban wa-sharqan). ${ }^{52}$ Another one, which has attracted substantial scholarly interest in recent years, is the partly preserved personal diary of the Damascene notary witness Ibn Ṭawq (ca. 1430-ca. 1510). ${ }^{53}$

Next to this study of a growing authorial presence in texts of history, attention in present-day scholarship has also been increasingly directed toward the authors' construction of their texts as acts that were not only intellectually and culturally but also socially and therefore historically meaningful in the unfolding of events and life stories. The work of George Makdisi in the early 196os and Fedwa Malti-Douglas in the late 1970s, rather than that of Rosenthal, somewhat inadvertently paved the way here. The former did so in a study on the history of Asharī speculative theology, in which he reinterpreted the famous biographical dictionary of Shafi'ì scholars by Tāj al-Dīn al-Subkī (ca. 1327-70), the mul-

49 Ibid. 204, 265.

$50 \quad$ See also Hirschler, Islam.

51 See Reynolds, Interpreting.

52 See Martinez-Gros, Ibn Khaldûn.

53 Wollina, Zwanzig; Shoshan, Damascus. 
tivolume Țabaqāt al-Shäfíciyya al-Kubrā, as a programmatic historiographical construct that attempted to redefine the boundaries of the Shafi'i community in both text and context, against the by the mid-14th century dominant exclusivity of Shafi'i traditionalism and in favor of Shafi'̄ Ash'arism and its tenets and champions. ${ }^{54}$ Malti-Douglas did so in her semiotic reading of a biographical dictionary of the blind, the Nakt al-Himyān fì Nukat al-'Umyān, by Khalī ibn Aybak al-Ṣafadì (d. 1363), in which she demonstrated how the literary reading of the biographical note as sign, its sociohistorical reading as signified, and the contextual reading of linguistic, cultural, and social codes informing the relationship between sign and signified cannot and should not be separated. ${ }^{55}$

Konrad Hirschler's $\mathrm{PhD}$ research, first published as a monograph in 2006 with the highly meaningful subtitle Authors as actors, eventually took these, many of the preceding, and some other overtures-especially also Tarif Khalidi's suggestion of the preponderance of a presentist and political (or siy$\bar{a} s a)$ orientation in late medieval Arabic historiography — many steps further. ${ }^{56}$ Hirschler's Authors as actors explains how two very different historians from the 13th century reported in their texts of history about similar events in very different ways, which made any questions of originality, authenticity, or veracity irrelevant. As Hirschler demonstrates, by employing different "modes of emplotment," these authors actively and purposefully used their authorial agency to make their texts meaningful in a direct dialogue- the one pursued from an "accommodationist" perspective, the other from a strongly "reformist" and even militantly traditionalist one-with the intellectual and social contexts in which they operated. ${ }^{57}$ Hirschler's approach in Authors as actors is one that therefore reconsidered textual constructed-ness with, as it were, Haarmann's qualified "literarization" as well as Little's intertextuality-originality as a complex whole of social and intellectual strategies that not only made texts of history but also history itself, or at least its individual or even collective ima-

54 Makdisi, Ash'arī and the Ash'arites.

55 Malti-Douglas, Dreams.

56 Hirschler, Authors; Khalidi, Arabic 182-231 (Chapter 5: History and siyasa). Apart from Khalidi, Hirschler also took explicit inspiration from the aforementioned Fähndrich and Malti-Douglas, as well as from al-Azmeh (al-Kitāba; L' annalistique; Histoire), from posthumously published work by Haarmann (Al-Maqrīzī), and from Conermann (Einige); Hirschler, Authors 128n13.

57 Hirschler, Authors 122-3; even though it has to be admitted that for Hirschler traditionalism was interpreted as a more limited, for mainly conservative, descriptive category, given that he argued that "it was therefore-paradoxically? —in the field of religious sciences that [Abū Shāma] could develop an outlook which was opposed to the traditionalist vision of society (p. 62)." 
ginations. This very promising focus on the performative nexus of authorial agencies and sociocultural strategies has so far only haphazardly been reemployed in current research on late medieval Syro-Egyptian history writing, whether for Hirschler's mid-13th century, Haarmann's, Little's, and Guo's early 14th century, or the exploding mass of authors and texts of the long $15^{\text {th }}$ century. 58

These more recent considerations of the changing constructed-ness of texts of history and the transformative authorial relationships with those texts and their late medieval Syro-Egyptian contexts have in different ways inspired the 13 contributions to this volume. These all represent therefore new readings in late medieval Arabic historiography. They do so not in the least because they stand for original contributions to modern scholarship by a new generation of junior scholars. They have been grouped in this volume in three parts of five or four chapters, each representing a different aspect of these new readings as well as its indebtedness to, especially, the Haarmann-Little tradition. Part one looks at concrete instances of intertextuality, from the perspectives of "literarized" historiographical practice as well as of "historicized" adab practices. Part two focuses on the creativity of authorial agencies and especially the performative textual strategies that were used-in forms often qualified as functions of "literarization" - to respond to changing intellectual and social contexts. Part three continues this line of enquiry but zooms in more precisely on the relationships between texts and social practice, in particular the textual performance of claims to identity and community membership.

In part one, Literarization as adabization: Intertextual agencies, Koby Yosef brings into focus and expands upon many of the issues at stake in this volume. In the chapter entitled "Al-Maqrīzì's Sulūk, Muqaffá, and Durar al- 'Uqüd," he engages directly with Haarmann's notion of "literarization," noting how in engagements with that historiographical model so far trends of "literarization" during the $15^{\text {th }}$ century have received less attention. In fact, Haarmann only summarily stated that al-Maqrīī's writing shows a "conservative anti-literary historiographical ethos." This chapter, however, argues that as a 15th-century Egyptian historian and Shāfi'i religious scholar, al-Maqrīzī combined Egyptian and (Shāfi î) scholarly historiographical trends in a more conscious and varied manner than Haarmann would allow. In his drawing on a Shāfici scholarly historiographic tradition, al-Maqrīzī did not incorporate entertaining story-like

$5^{8}$ For the 12th and early 13th centuries, see Hirschler, Jerusalem; for the 13th and early 14th centuries, see Van den Bossche, Performance; for the 14th and 15th centuries, see Van Steenbergen, Qalawunid; Caliphate; Van Steenbergen and Van Nieuwenhuyse, Truth. 
reports with dialogues in accounts of contemporary events. In contrast, past events and biographies of notables of the past could be used to some degree for entertainment purposes, drawing in standardizing ways on the earlier achievements of Egyptian chroniclers related to the military institution and on an anecdotal tradition of biographical dictionaries.

Koby Yosef's second chapter, "Language and style in Mamluk historiography," continues this engagement with the notion of the "literarization" of late medieval Arabic history writing from the particular perspective of the uses of linguistic registers in historiography. The increasing use of nonstandard Arabic has been considered one of the most noticeable characteristics of "literarization," which went hand in hand with the increasing use of stylistic elements drawn from the literature of adab. To date, however, there have not been too many attempts at an overall survey of different trends of language use covering all major historians throughout the late medieval period. This paper offers such an overall survey and suggests that a differentiation should be made between subgroups of historians who were religious scholars. It is argued that usages of nonstandard Arabic are typical of historians related to the military institution and non-Shāfi'ì religious scholars. On the other hand, Shāfi'ì religious scholars refrained from using nonstandard Arabic and standardized nonstandard usages in their quoted sources because of the importance of the Arabic language in their ethos. The trends of language use are examined in tandem with one stylistic element: the incorporation of story-like reports with dialogues and direct speech in accounts of contemporary events in the historical narrative in chronicles. This allows a more nuanced differentiation between trends of language use and style. It is argued that in terms of language use and style, non-Shāfīi religious scholars take a middle ground between historians related to the military institution and historians who were Shāfici religious scholars.

Victor De Castro León's “Ibn al-Khațîb and his Mamluk reception” focuses on the figure of one of the most important polymaths and viziers in the history of al-Andalus and of 14th-century Granada in particular, Lisān al-Dīn Ibn al-Khațib (1313-74). Ibn al-Khațib was very interested in spreading his intellectual production in the West and East and employing, for this purpose, all the means that were at his disposal. The latter included his high political position as well as his important intellectual network of peers and students. Two other Maghrebi authors who had settled in Cairo contributed substantially to his success in the East: Ibn Khaldūn and Ibn Abī Hajala. This chapter studies the role of this triple relationship through the testimonies from these three authors that demonstrate how this network operated and how Ibn al-Khațib's works were received and used, not only by these two Maghrebi authors but also by other 
Syro-Egyptian authors who knew and employed the works of the Granadian vizier in the 14th and $15^{\text {th }}$ centuries.

Tarek Sabraa's "Ibn Qāḍī Shuhba (1377-1448): His life and historical work" presents an in-depth investigation of the life, family history, and historical work of one of the most important historians of the history of al-Shām in the late medieval period: Ibn Qādị Shuhba (1377-1448). This author is mainly known for his works on figh, but the chapter reveals that his historical works are far more numerous and represent a rare source for the history of al-Shām at his time. This reconstruction of the family history of Ibn Qâdị Shuhba aims to shed light on two different aspects. The first one involves the establishment in this period of substantial numbers of scholarly families and their accession to influential positions in society. The second issue concerns the origins of the author's family and how they might be key to explaining his particular approach to history writing and revealing the underlying motives that influenced his work. The intensive study of Ibn Qāḍi Shuhba's family history, therefore, not only serves as a perfect example of how the scholarly environment during this period developed and was consolidated; it can also help us to understand the personal prefiguration that informed this author's perspective on history.

Iria Santas's "Andalusi adab in the Mamluk period" focuses on one of the first and most important Andalusi adab authors, the Cordovan Ibn 'Abd Rabbihi (86o-940), who was an important figure during the splendor of the 1othcentury Umayyad Cordovan Caliphate of 'Abd al-Rahmmān III. This chapter tries to reconstruct the reception process in the Islamic East of his most important work, the well-known al-Iqd al-farid. Despite the importance of this adab encyclopedia as one of the first dated Arabic texts that was produced in alAndalus, its full impact inside and outside al-Andalus remains to be investigated. This chapter uses the testimonies of Andalusi, Maghrebi, and Easternmainly Syro-Egyptian - authors who employed this work to study the transmission of Ibn 'Abd Rabbihi's main work to the Islamic East and its reception and influence in later Eastern adab works.

In this volume's part two, Literarization as creative authorship: Contextual agencies, Mohammad Gharaibeh identifies some of the complex social and intellectual stakes that have to be taken into account in any consideration of historiographical practice. The case study presented in his chapter "Social and intellectual rivalries and their narrative representations" considers the stakes involved in the construction of one of the most important sources of knowledge on premodern Muslim individuals: biographical dictionaries. Against the common approach in modern research to treat biographical dictionaries as archives of (neutral) information about individuals, this article looks at them as producers of (biased) knowledge that conveys the intention and (hidden) 
agenda of the authors. This case study zooms in on the biographical entries on the Damascene scholar Ibn al-Ṣalāḥ (d. 1245) in the biographical dictionaries of three authors of this period. These are al-Dhahabi (d. 1348) with his works Siyar a 'àm al-nubalā’, Tārīh al-islām, and Tadhkirat al-huffāz, Ibn Kathīr (d. 1373) with his work Ṭabaqāt al-Shäfíiyya, and Tāj al-Dīn al-Subkī (d. 1370) with his work Tabaqāt al-Shäfiiyya al-kubrā. An analysis of their narrative strategies reveals the different images they created of Ibn al-Ṣalāh and the different messages they communicated. In addition, a contextualization of the authors within the social and intellectual contexts of Damascus, especially of its traditionalist and rationalist communities of scholars, allows for the identification of the authors' motivations that stood behind their narrative strategies.

Zacharie Mochtari de Pierrepont's chapter "Ibn Ḥajar al-'Asqalān̄̄'s texts and contexts" aims to raise a number of questions related to historiographical discourses about scholars and ascetics specifically identified as Sufis by Ibn Hajar al-Asqalānī in the annalistic chronicle Inbä' al-ghumr bi-abnä al-umr. It draws attention to the different discursive strata Ibn Hajar elaborated to create a particular view on contemporary Sufi characters. Furthermore, it documents part of the Sufi environment of the Cairo sultanate as it is introduced in the Inb $\vec{a}$. Doing so, Ibn Hajar shaped a specific social, cultural, and political order in which Sufism and Sufi characters were presented as part of the dynamics of power that were crafted in the chronicle. They were presented as participating in these dynamics by way of the normative production and legitimation of power relationships, as these were understood in the chronicle's own discursive contextual framework. From this example, this chapter thus argues that the Inb $\vec{a}^{3}$ participated in building a new perspective for Ibn Hajar's own historiographical positions and assertive opinions, shaping new memories that crafted new historical narratives.

Rasmus Ollsen's chapter "If a governor falls in Damascus" examines how four Damascene scholar-chroniclers and two Egyptian soldier-chroniclers narrate the demise of Amir Sayf al-Dīn Karāy al- Manșūī, the sultan's viceroy of Damascus, in 1311. Karāy was arrested and exiled to Karak in present-day Jordan only four months into his governorship. His dramatic departure from Damascus is attributed to both local protests against his taxation methods and his alleged participation in a military coup d'état against Sultan al-Nāșir Muhammad b. Qalāwūn (r. 1293-4, 1299-1309, 1310-41). This overlap between a local and a regional political context has ensured the arrest of Karāy a place in several Syrian and Egyptian chronicles, which makes it an excellent case for a comparative historiographic analysis that considers both collective and personal authorial agendas. Firstly, this chapter shows how the social and geographic backgrounds as well as the shared values and interests of the Syrian and Egyp- 
tian authors, respectively, influence their choice of focus when narrating the story of Karāy's arrest. Secondly, by demonstrating how personal, ideological, and doctrinal disagreements also permeate the individual portrayals of Karāy, the chapter argues that each author must also be regarded as an actor with a personal agenda in addition to being a member of a geographically and socially defined group.

Clément Onimus's chapter "Al-'Aynī and his fellow historians" aims to define the social position of the 15th-century scholar al-'Ayni through the historiographical writings of his contemporaries and students. It first considers his biographies by his peers and rivals, al-Maqrīzì and Ibn Ḥajar al-'Asqalānī, as well as the auto-documentary notes in his own chronicles. These sources create a polyphonic representation of this historian and judge. All three authors emphasize the same events and topics, given that al-'Aynī answers in his own works to the criticisms he is submitted to by his colleagues: his competence in the performance of offices, his relationships of dependence and interdependence with the military milieu, and his literary skills. On the whole, history writing appears as a means of communication that creates a dialogue between prominent scholars. In this dialogue, the social position of al-'Ayni cannot be understood separate from this narrative; what appears is rather a persona on the stage of historical writing. Later historians relied on the works of their predecessors and the evolution of al-Ayni's situation. As he became one of the highest dignitaries of the sultanate and one of the teachers of several later scholars (notably Ibn Taghrī Birdī and al-Sakhāwī), he is acclaimed by most of them, although no one conceals the conflicts he had with his colleagues. Out of these rivalries, in their biographies they elaborate a consensual memory where al-Ayni becomes a key figure in the competitive world of Islamic scholarship.

In part three, Literarization as social practice: Textual agencies, Kenneth Goudie introduces the characteristic of authorial self-representation and its interconnecting of textual performance and intellectual as well as social stakes. His chapter "Al-Biqāî's self-reflection" engages with the historiography of Burhān al-Dīn al-Biqā̄î̀ (1406-80), a 15th-century Quran exegete and historian. When discussing the life of al-Biqāî̀, modern scholarship has primarily focused on his later career and the controversies in which he became embroiled. But comparatively little has been written about his formative years. This is despite the fact that, at the age of 32 , he wrote an autobiography of his early life, which is contained within his 'Unwān al-zamān bi-tarājim al-shuyūkh wa-l-aqrān. Taking inspiration from the Geertzian concept of "thick description," this chapter moves beyond a brief and positivist reconstruction of al-Biqāâi's life and treats his autobiography not merely as an innocent record of his early life through which we can reconstruct the chronology of his formative years but also as a 
carefully crafted literary work in its own right. The contention of this chapter is that al-Biqāî's autobiography can be read in two ways: one simple and textual; the other complex and subtextual. On the one hand, it can be read in a positivist fashion as a straightforward account of his formative years; on the other hand, it can be read as an attempt to give deeper meaning to those years. The chapter takes a twofold approach to the autobiography, dealing firstly with what al-Biqāì tells us about his formative years before moving on to explore how al-Biqāi sought to give them social and cultural meaning. It argues that the autobiography was meant to justify his membership among the sultanate's intellectual elite, while simultaneously framing his life as fundamentally guided by God.

Christian Mauder's chapter "And they read in that night books of history" engages with the accounts of the majälis or learned gatherings convened by the penultimate sultan of Cairo Qānișawh al-Ghawrī (r. 1501-16) at the Cairo Citadel. These accounts provide deep insight into the dynamics of the consumption, performative presentation, and production of texts about the past at al-Ghawri's court. Moreover, they indicate that members of the sultan's court invested considerable time, effort, and cultural capital into engaging with historiographical material. The chapter argues that this engagement was part of a dense web of social practices that served multiple purposes, including but not limited to, the representation and legitimation of al-Ghawri's rule, the exchange and acquisition of cultural capital, the performative enactment and reaffirmation of the courtiers' membership in a refined elite of $u d a b \vec{a}^{\text {' (i.e., }}$ persons possessing $a d a b$ ), the social construction of a shared reality, the commemoration of events central to the identity of members of the court, and the enjoyment of aesthetic pleasure. These findings highlight the importance of courts of the Islamic late middle period in the production and consumption of Arabic literature and underscore that the concept of $a d a b$ functioned as an overarching frame of reference that members of the sultanic court in Cairo used to imagine and construct their own place in the world.

Ivan Metzger's chapter "Historical representation as resurrection" presents an analysis of al-Tālic al-Saìd by al-Udfuwī (d. 1347), looking in particular into the tamhid, or laudatory prelude, of this biographical dictionary of Upper Egypt. The tamhìd is a ubiquitous element of classical Arabic writing. Arabic literary critics indicated its close relationship to the subject matter of the entire literary composition. This paper shows how form and content intertwine in al-Udfuwiss biographical history of Upper Egypt to produce a symbolic imitation of God's creation. As indicated in his tamhid, history, like the Resurrection, revives the memories of past lives, both good and bad. Faithful to this metaphor of his own creation, al-Udfuwī revives a range of characters, not just those 
who reflect positively on his beloved Upper Egypt. The result is a polyphony of voices, from the irreverent or heretical to the pious and orthodox. Yet, far from allowing the reader to form a neutral judgment of this carnival of resurrected lives, al-Udfuwī, through selective editorializations and omissions, pushes his reader to view Upper Egypt as a bastion of Sunnism that has cast aside its previous heterodoxy.

Finally, Gowaart Van Den Bossche's chapter "Literarisierung reconsidered in the context of sultanic biography" aptly closes this part and this volume of new readings in Arabic historiography. It revisits Haarmann's "literarization" thesis and the related debates on the historiographical practice of knowledge- and truth-making, challenging Haarmann's conceptualization and reconsidering the relationship between literary forms and historiography. This reconceptualization is illustrated by discussing a hitherto unpublished and understudied text belonging to the regnal biography genre and found in the manuscript Arabe 1705 of the Bibliothèque Nationale in Paris. This undated manuscript can be identified as part of a biography of Sultan al-Malik al-Nāșir Muhammad (r. 1293-4, 1299-1309, 1310-41) by the Egyptian chancery scribe and man of letters Shāfí b. 'Alī (d. 1330). Containing alternate accounts of a crucial phase in alNāșir Muhammad's career, especially the period leading up to his third ascent to the throne during the short-lived sultanate of al-Muzaffar Baybars (r. 130910 ), this surviving part is of great interest to historians studying this period. Similar to Shāfi's better-known biographies of the sultans Qalāwūn (r. 1279-9o) and Baybars (r. 126o-77), the text also offers much material for the study of the fruitful intersection of adab, especially as it was cultivated in the chancery and historiography. The majority of the text is written in $s a j^{c}$ (rhymed prose), frequently includes (self-written) poems, correspondence, and official documents and is replete with panegyrical passages. Furthermore, a large part of the surviving text transcends chronography and integrates historical happenings into a powerful and recognizable heroic narrative of the loss and reclaiming of power.

\section{Bibliography}

\section{Secondary Sources}

Al-Azmeh, A., Al-Kitāba al-tärīkhiyya wa-l-ma'rifa al-ta’rīkhiyya, Beirut 1983.

Al-Azmeh, A., L' annalistique entre l' histoire et le pouvoir: une conception de l'histoire sous-jacente aux chroniques, biographies et gestes dan l'aire culturelle araboislamique, in unesco (ed.), Histoire et Diversité des Cultures, Paris 1984, 95-116.

Al-Azmeh, A., Histoire et narration dans l'historiographie arabe, in Annales, Histoire, Sciences Sociales 41/2 (1986), 411-31. 
Bauden, F., Maqriziana I: Discovery of an autograph manuscript of al-Maqrīzī: Towards a better understanding of his working method, description: Section 1, in $M S R$ 7/2 (2003), 21-68.

Bauden, F., Maqriziana Iv: Le Carnet de Notes d' al-Maqrīzī: l' Apport de la Codicologie à une Meilleure Compréhension de sa Constitution, in Manuscripta Orientalia 9/4 (2003), 24-36.

Bauden, F., Maqriziana I: Discovery of an autograph manuscript of al-Maqrīzī: Towards a better understanding of his working method: Analysis, in MSR 12/1 (2008), 51-118.

Bauden, F., Maqriziana vııı: Quelques Remarques sur l' Orthographies d' al-Maqrîzî (m. 845/1442) à Partir de son Carnet de Notes: Peut-on Parler de Moyen Arabe?, in J. Lentin and J. Grand'Henry (eds.), Moyen Arabe et Variétés Mixtes de l'Arabe à Travers l'Histoire, Louvain-la-Neuve 2008, 21-38.

Bauden, F., Maqriziana XI. Al-Maqrīzī et al-Ṣafadī: Analyse de la (Re)Construction d' un Récit Biographique, in Quaderni di Studi Arabi, Nuova Serie 5 (2009), 99-136.

Bauden, F., Maqriziana Ix: Should al-Maqrīzì be thrown out with the bath water? The question of his plagiarism of al-Awhadì's Khițat and the documentary evidence, in MSR 14 (2010), 159-232.

Bauden, F., Al-Maqrīż’s collection of opuscules. An introduction (Bibliotheca Maqriziana 1) Leiden, forthcoming.

Bauer, T., Mamluk literature: Misunderstandings and new approaches, in $M S R$ 9/2 (2005), 106-32.

Bauer, T., "Ayna hādhā min al-Mutanabbī!" Toward an aesthetics of mamluk literature, in $M S R 17$ (2013), $5^{-22 .}$

Bauer, T., Mamluk literature as a means of communication, in S. Conermann (ed.), Ubi Sumus? Quo Vademus?, Gottingen 2013, 159-86.

Blochet, E., Moufazzal b. Abi l-Fazaiil: Histoire des sultans mamelouks. Texte arabe publié et traduit en français, in Patrologia Orientalis 12/3-59 (1916), 345-550.

Bora, F., Writing history in the medieval Islamic world: The value of chronicles as archives, London 2019.

Cahen, C., Review of An introduction to Mamlūk historiography, by Donald P. Little, and Quellenstudien zur frühen Mamlukenzeit, by Ulrich Haarmann, in JESHO 15/2 (1972), 223-5.

Conermann, St., Einige allgemeine Überlegungen zum vormodernen "Historischen Denken" der Araber, in $0 L Z 93$ (1998), 141-57.

Fähndrich, H.E., Man and men in Ibn Khallikān: A literary approach to the Wafayāt alA'yān, PhD diss., University of California 1972.

Fähndrich, H.E., The Wafayāt al-a'yān of Ibn Khallikān: A new approach, in JAOs 93/4 (1973), 432-45.

Fähndrich, H.E., Compromising the caliph: Analysis of several versions of an anecdocte about Abū Dulāma and al-Manșūr, in JAL 8 (1977), 36-47. 
Glassen, E., Zum Gedenken: Ulrich Haarmann (22.9.1942-4.6.1999), in Die Welt des Islams 40/3 (2000), 335-43.

Guo, L., Mamluk historiographic studies: The state of the art, in MSR 1 (1997), 15-43.

Guo, L, Early Mamluk Syrian historiography: Al-Yūnīnı̀s dhayl mir’at al-zamān, i, (IHC 21), Leiden 1998.

Haarmann, U., Quellenstudien zur frühen Mamlukenzeit, Freiburg im Breisgau 1970.

Haarmann, U., Auflösung und Bewahrung der klassischen Formen arabischer Geschichtsschreibung in der Zeit der Mamluken, in ZDMG 1/121 (1971), 46-6o.

Haarmann, U., Review Weltgeschichte und Weltbeschreibung im mittelalterlichen Islam by Bernd Radtke, in JAOS 115/1 (1995), 133-5.

Haarmann, U., Al-Maqrīzī, the master, and Abū Ḥāmid al-Qudsī, the disciple-whose historical writing can claim more topicality and modernity?, in H. Kennedy (ed.), The historiography of Islamic Egypt (c. 950-1800) (The Medieval Mediterranean 31), Leiden 2001, 149-65.

Herzog, T., Geschichte und Imaginaire: Entstehung, Überlieferung und Bedeutung der Sirat Baibars in ihrem sozio-politischen Kontext, Wiesbaden 2006.

Hirschler, K., Medieval Arabic historiography: Authors as actors, London 2006.

Hirschler, K., The written word in the medieval Arabic lands: A social and cultural history of reading practices, Edinburgh 2012.

Hirschler, K., Islam: The Arabic and Persian traditions, eleventh-fifteenth centuries, in S. Foot and C. Robinson (eds.), The Oxford history of historical writing, ii, Oxford 2012, 267-86.

Hirschler, K., Studying Mamluk historiography. From source-criticism to the cultural turn, in S. Conermann (ed.), Ubi sumus? Quo Vademus?, Gottingen 2013, 159-86.

Hirschler, K., The Jerusalem conquest of 492/1099 in the medieval Arabic historiography of the Crusades: From regional plurality to Islamic narrative, in Crusades 13 (2014), 37-76.

Hirschler, K., From archive to archival practices: Rethinking the preservation of Mamluk administrative documents, in JAOS 136/1 (2016), 1-28.

Hirschler, K., Medieval Damascus: Plurality and diversity in an Arabic library: The Ashrafìa Library catalogue, Edinburgh 2016.

Hirschler, K., A monument to medieval Syrian book culture: The library of Ibn 'Abd alHādī, Edinburgh 2020.

Holtzman, L., Anthropomorphism in Islam: The challenge of traditionalism (700-1350), Edinburgh 2018.

'Izz al-Dīn, M.K., Ibn Hajar al-'Asqalānī Mu'arrikhan, Beirut 1407/1987.

'Izz al-Dīn, M.K., 'Abd al-Bāsiṭ al-Hanafì Mu’arrikhan, Beirut 1410/199o.

'Izz al-Dīn, M.K., al-Maqrīzī Mu'arrikhan, Beirut 1990.

'Izz al-Dīn, M.K., Arba'at Mu'arrikhìn wa-Arba'at Mu'allafāt min Dawlat al-Mamālīk alJarākisa, Cairo 1992. 
Khalidi, T., Arabic historical thought in the classical period, Cambridge 1994.

Little, D., An introduction to Mamluk historiography: An analysis of Arabic annalistic and biographical sources for the reign of al-Malik an-Nașir Muhammad ibn Qala'un, Montreal 1970.

Little, D., Historiography of the Ayyūbid and Mamlūk epochs, in C.F. Petry, The cambridge history of Egypt, Cambridge 1998, 412-44.

Makdisi, G., Ash`arī and the Ash'carites in Islamic religious history I, in $S I 17$ (1962), 378 o.

Malti-Douglas, F., Dreams, the blind, and the semiotics of the biographical notice, in $S I$ 51 (1980) 137-62.

Martinez-Gros, G., Ibn Khaldûn et les sept vies de l'Islam, Arles, 2006.

Massoud, S.G., Notes on the contemporary sources of the year 793, in MSR 9/1 (2005), 163-206.

Massoud, S.G., The Chronicles and Annalistic Sources of the Early Mamluk Circassian Period, Leiden 2007.

Massoud, S.G., Donald Presgrave Little, 1932-2017, in MSR 20 (2017), 1-2.

Meloy, J.L., Imperial power and maritime trade: Mecca and Cairo in the later middle ages, Chicago 2010.

Muhanna, E., The world in a book: Al-Nuwayri and the Islamic encyclopedic tradition, Princeton and Oxford 2017.

Pauliny, J., Die Anekdote im Werke Ibn Huallikāns, in Asian and African studies 3 (1967), 141-56.

Perho, I., Al-Maqrīzī and Ibn Taghrī Birdī as historians of contemporary events, in H. Kennedy (ed.), The historiography of Islamic Egypt (c. 950-1800) (The Medieval Mediterranean 31), Leiden 2001, 107-20.

Perho, I., Ibn Taghrïbirdīs portrayal of the first Mamluk rulers, Berlin 2013.

Perho, I., Ibn Taghrībirdì's Voice, in S. Akar, J. Hämmeen-Antilla and I. Nokso-Koivisto (eds.), Traveling through time: Essays in honour of Kaj Öhrnberg (Studia Orientalia 114) Helsinki 2013, 135-47.

Petry, C.F., Protectors or praetorians?: The last Mamlūk sultan's and Egypt's waning as a great power, New York 1994.

Radtke, B., Weltgeschichte und Weltbeschreibung im mittelalterlichen Islam, Beirut Stuttgart 1992.

Reynolds, D.F., Interpreting the self: Autobiography in the Arabic literary tradition, Berkeley 2001.

Richter, G., Das Geschichtsbild der arabischen Historiker des Mittelalters, Tübingen 1933.

Rosenthal, F., A history of Muslim historiography, Leiden 1968.

Sadek, N., Notes on the Rasulid historian al-Hazrajij's career as a craftsman, in Proceedings of the seminar for Arabian studies 27 (1997), 231-3.

Schregle, G., Die Sultanin von Ägypten: Šăgarat ad-Durr in der arabischen Geschichtsschreibung und Literatur, Wiesbaden 1961. 
Shoshan, B., Poetics of Islamic historiography: Deconstructing Tabarı’s history (I HC 53), Leiden 2004.

Shoshan, B., Damascus life 1480-1500: A report of a local notary (IHC 168), Leiden 2019. Tadayoshi, K., An analysis of 'Abd al-Bāsiț al-Hanafi's description of the year 848: On the process of writing history in the late fifteenth century, in MSR 10/1 (2006), 29-54.

Van den Bossche, G., The past, panegyric, and the performance of penmanship: Sultanic biography and social practice in late medieval Egypt and Syria, PhD diss., Ghent University, 2019 .

Van Steenbergen, J., Qalāwūnid discourse, elite communication and the Mamluk cultural matrix: Interpreting a 14th-century panegyric, in JAL 43 (2012), 1-28.

Van Steenbergen, J., "Mamlukisation" between social theory and social practice: An essay on reflexivity, state formation, and the late medieval sultanate of Cairo, ASK Working Paper 22 (2015).

Van Steenbergen, J., Caliphate and kingship in a fifteenth-century literary history of Muslim leadership and pilgrimage. Critical Edition, annotated translation, and study of Al-Dhahab al-Masbūk fĩ Dhikr man Hajja min al-Khulafā’ wa-l-Mulūk (Bibliotheca Maqriziana 4), Leiden 2016.

Van Steenbergen, J., and S. Van Nieuwenhuyse, Truth and politics in late medieval Arabic historiography: The formation of Sultan Barsbāy's state (1422-1438) and the narratives of the amir Qurqumās al-Sha'bānī (d. 1438), in Der Islam 95/1 (2018), 14788.

Van Steenbergen, J., M. Banister, K.A. Goudie, M. Maslouh, Z. Mochtari de Pierrepont and R. Ben Othmen, Fifteenth-century Arabic historiography: Introducing a new research agenda for authors, texts and contexts, in MSR 23 (2020) (forthcoming).

von Grunebaum, G., Medieval Islam: A study in cultural orientation, Chicago and London 1953 .

Wasserstein, D.W., Tradition manuscrite, authenticité, chronologie et développement de l'oeuvre d' Ibn Iyās, in JA 280/1 (1992), 81-114.

Weintritt, O., Formen spätmittelalterlicher Islamischer Geschichtsdarstellung: Untersuchungen zu an-Nuwairī al-Iskandarānīs Kitāb al-ilmām und verwandten Zeitgenössischen Texten (вт 45), Beirut Stuttgart 1992.

Wollina, T., Zwanzig Jahre Alltag: Lebens-, Welt- und Selbstbild im Journal des Aḥmad Ibn Tawq, Göttingen 2014 . 